\title{
PSAT1 wt Allele
}

National Cancer Institute

\section{Source}

National Cancer Institute. PSAT1 wt Allele. NCI Thesaurus. Code C113277.

Human PSAT 1 wild-type allele is located in the vicinity of $9 q 21.2$ and is approximately 33 $\mathrm{kb}$ in length. This allele, which encodes phosphoserine aminotransferase protein, plays a role in the biosynthesis of amino acids. Mutation of the gene is associated with phosphoserine aminotransferase deficiency. 